\title{
Freezing of stallion semen: I - In vitro evaluation of motility and acrosin activity in sperm cells cryopreserved under different glycerol concentrations
}

\author{
José Carlos Ferreira-Silva', Jorge Motta Rocha², Sarah Romini Lima Basto', Heder Nunes Ferreira ${ }^{3}$, Helder Melo Souza ${ }^{4}$, \\ Leopoldo Mayer Freitas Neto', Marcelo Tigre Moura', Marcia Cristina Cavalcanti Oliveira' and Marcos Antonio Lemos Oliveira'
}

\footnotetext{
1 Laboratorio de Biotécnicas Reprodutivas, Universidade Federal Rural de Pernambuco, Recife-PE, Brasil

2 Universidade Federal do Rio Grande do Norte, Natal-RN, Brasil

${ }^{3}$ Faculdade Pio Décimo - Hospital Veterinário, Aracaju-SE, Brasil
}

\begin{abstract}
Summary: The aim was to verify the efficiency of different glycerol concentrations (1\%, 3\%, and 5\%) for cryopreservation of stallion semen. After semen collection, sperm cells were evaluated for motility and acrosin activity. The semen was divided into three equal parts and resuspended in freezing diluent without glycerol in a 1:1 proportion and were incubated for 20 minutes at room temperature. Immediately after centrifugation for 10 minutes at $600 \mathrm{~g}$ and discarding the supernatant, each pellet was diluted with the same diluent and further centrifuged for 10 minutes. After the second centrifugation, each pellet received freezing glycerol-containing diluent under concentrations of $1 \%, 3 \%$, and $5 \%$ and was loaded in $4 \mathrm{~mL}$ macro-tubes. These macro-tubes were placed in liquid nitrogen vapor for 15 minutes for immediate immersion in liquid nitrogen and storage at $-196^{\circ} \mathrm{C}$. After thawing at $50^{\circ} \mathrm{C}$ for 40 seconds, semen samples were initially evaluated for sperm motility and acrosin activity. Moreover, semen was also incubated at $37^{\circ} \mathrm{C}$ and evaluated for sperm motility after 60 and 120 minutes in a thermoresistance test (TRT). Immediately after thawing and during the TRT, both progressive and total sperm motility was lower in $1 \%$ glycerol $(P<0.05)$ than those frozen with 3 and $5 \%$ of this cryoprotectant, while there was no difference $(P>0.05)$ between these two later concentrations. The acrosin activity in fresh semen was only greater $(\mathrm{P}<0.05)$ than those frozen with $1 \%$ glycerol that was also lower than both semen with $3 \%$ and $5 \%$ of this cryoprotectant, although there was no difference $(P>0.05)$ between these later glycerol concentrations. In conclusion, based on sperm motility and acrosin activity, that $3 \%$ and $5 \%$ glycerol concentrations are suitable for stallion semen cryopreservation.
\end{abstract}

Keywords: reproduction, cryopreservation, dilvent, spermatozoa, stallion

Citation: Ferreira-Silva J. C., Motta Rocha J., Romini Lima Basto S., Nunes Ferreira H., Melo Souza H., Mayer Freitas Neto L., Moura M. T., Cavalcanti Oliveira M. C., Oliveira M. A. L. (2018) Freezing of stallion semen: 1. In vitro evaluation of motility and acrosin activity in sperm cells cryopreserved under different glycerol concentrations. Pferdeheilkunde 34, 51-55; DOI 10.21836/PEM20180109

Correspondence: Jose C. Ferreira-Silva M.Sc., Laboratory of Reproductive Biotechniques, Department of Veterinary Medicine, University Federal Rural de Pernambuco, Recife, Brazil; ferreirasilva.jc@gmail.com

\section{Introduction}

During the process of cryopreservation, sperm cells are exposed to diverse stress conditions, with great variation of temperature that is non-physiological. Furthermore, there is formation and dissolution of ice crystals during the cryopreservation process, that further compromises sperm cell viability (Holt 2000, Watson 2000). Due to this reason, diluent media are formulated with extracellular and intracellular cryoprotectants, to protect sperm cells and minimizes damage provoked during freezing and thawing processes (Amann and Pickett 1987).

Among several intracellular cryoprotectants, glycerol is the mostly used penetrating agent in diluent media for semen cryopreservation for most domestic species. This substance is a polyhydric alcohol that is highly permeable and has the capacity of making osmotic dehydration slower during cryopreservation, thus impeding the formation of large intracellular ice crystals (Watson 2000). However, the toxicity of glycerol can lead to protein denaturation, may cause changes in cytoplasmic events, and alterations in the sperm membrane (Curry 2000, Holt 2000).

Some authors established variable glycerol concentrations, from 3.5\% (Nagase et al. 1966b), $4 \%$ (Rajamannan et al, 1968), or 5\% (Martin et al 1979). These studies gained the attention of other researchers that used different concentrations of this cryoprotectant in order to minimize the damage of freezing/thawing in sperm cells (Nishikawa et al. 1968, Nishikawa et al. 1972, Pace and Sullivan 1975, Guay et al. 1981, Cochram et al. 1984, Amann and Picket 1987, Watson 1995, Vidament et al. 2001).

Since the report of Smith and Polge (1950), the leading problem of semen cryopreservation has been linked to short-lived sperm motility after thawing. Both Merkt and Krause (1966) and Nagase et al. (1966a) reported lower sperm motility after thawing (within 20 to $30 \%$ ) for horse semen cryopreserved as pellets. Even after the advent of straws (Nishikawa et al. 1968) and macro-tubes (Martin et al. 1979), as replacements of pellets for semen storage, these methods give better protection to the sperm cell during cryopreservation (Vieira and Klug 1982). However, a significant decrease in sperm motility is still observed after semen thawing under such conditions (Santos et al. 2015).

Since the factors that determine the fertilizing potential of thawed semen cannot be wholly elucidated by routine methods used in clinics or reproduction centers (López-Fermandez et al. 2007), other far more sophisticated sperm parameters have been experimentally included in semen evaluation protocols (Ferreira et al. 2018). However, even without taking 
into consideration the impossibility of adopting such protocols in the daily routine of andrological examinations due to its limited practicability, these evaluations have limited potential due to its high cost and the requirement of sophisticated equipment (Enciso et al. 2006, Ferreira et al. 2018).

Acrosin is a proteolytic enzyme found in the sperm acrosome (Penn et al. 1972) that is important during the process of fertilization (Bedford 1968). Its activity was also described by Wendt et al. (1975) and was later measured in horse sperm cells by Vieira and Klug (1982). In contrast to other tests, it does not require for sophisticated equipment and its activity is also directly related to acrosome integrity (Penn et al. 1972, Wendt et al. 1975, Ferreira-Silva et al. 2018).

In light of the facts above, the aim was to evaluate the effect of different glycerol concentrations on stallion semen cryopreservation, using motility and acrosin activity as sperm parameters to validate an adequate concentration of this cryoprotectant on the freezing diluent.

\section{Material and methods}

The semen of two Hanoverian stallions, with ages of six and ten years, under a breeding regimen, were used for testing different glycerol concentrations for sperm cryopreservation. The semen collection was carried out twice a week with an artificial vagina warmed approximately at $42^{\circ} \mathrm{C}$ and also using teasing mares.

Ejaculates $(n=20)$, where 10 of each stallion, were initially filtered to discard the gel and the volume was measured in a tube with a measuring scale. Immediately after, a semen aliquot of fresh semen was obtained to evaluate the semen for motility, concentration, supravital coloring, and sperm cell morphology in a contrast-phase microscope with a heated stage. These evaluations were performed by an experienced evaluator that was unaware of the experimental conditions as according to the previous report by Fayrer-Hosken et al. (2008). The acrosin activity was determined by the method described by Vieira and Klug (1982).

The semen was added to an 11\% lactose solution in a 1:1 proportion and remained at room temperature for 20 minutes (Martin et al. 1979). Immediately after this period, the semen was divided into three equal parts and further distributed in three glass tubes for centrifugation for 10 minutes at $600 \mathrm{~g}$. After discarding the supernatant, each pellet was re-diluted with the same diluent and again centrifuged for 10 minutes.

After the second centrifugation, the pellets were diluted in freezing diluent $[50 \mathrm{~mL}$ of $11 \%$ lactose solution; $25 \mathrm{~mL}$ of MERCK diluent (Merck-Verdünnungsmischung I für Ebersperma mit Antibiotika-Zusatz; Fa. Merck, Darmstadt - Germany); $20 \mathrm{~mL}$ of egg yolk; $0.8 \mathrm{~mL}$ of Orvus-Paste (Equex STM, Fa. Procter \& Gamble, Cincinnati, Ohio, USA) according to Martin et al. (1979). Moreover, the freezing diluent was glycerolized $(1,3$ or $5 \%$ glycerol) and semen samples were resuspended to obtain a final concentration of $200 \times 10^{6}$ viable sperm cells $\mathrm{mL}^{-1}$.

After thawing at $50^{\circ} \mathrm{C}$ for 40 seconds, semen samples were initially assessed for sperm motility and acrosin activity Immediately after, the semen was incubated at $37^{\circ} \mathrm{C}$ and evaluated for motility at 60 and 120 minutes in a thermoresistance test (TRT).

The data were analyzed for normality distribution by the Shapiro-Wilk test. The data in percentages was transformed by arc sen $\sqrt{ }$ and were further subject to ANOVA. Comparison of means was performed using the Tukey - Krammer test with significance level of $5 \%$.

\section{Results}

Despite not being used for the statistical analysis, the data collected as percentages of sperm motility, acrosome alterations, and acrosin activity are displayed, at all tables, inside parenthesis and immediately below the data transformed by the $\operatorname{arc} \operatorname{sen} \sqrt{ }$.

The progressive sperm motility did not differ between the fresh semen and the semen that was mixed with diluent after two centrifugation steps, independently of glycerol concentration. For both fresh semen and that pre-frozen samples of the two stallions, this motility was higher $(P<0.05)$ than the thawed semen, irrespectively of glycerol concentration and the stallion.

Immediately after thawing, sperm motility using $1 \%$ glycerol was lower $(P<0.05)$ than those from 3 and $5 \%$ glycerol, whi-

Table 1 Mean values $(x \pm S D)$ of data transformed by arc sen $\sqrt{ }$ and as percentages in parenthesis of progressive sperm motility as fresh, prefreezing, and thawed samples.

\begin{tabular}{|c|c|c|c|c|c|c|c|}
\hline \multirow[b]{2}{*}{ Animal } & \multirow[b]{2}{*}{ Fresh } & \multicolumn{3}{|c|}{ Pre-Freezing } & \multicolumn{3}{|c|}{ Post-Freezing (Thawed) } \\
\hline & & $\begin{array}{c}\text { Glycerol } \\
1 \%\end{array}$ & $\begin{array}{c}\text { Glycerol } \\
3 \%\end{array}$ & $\begin{array}{c}\text { Glycerol } \\
5 \%\end{array}$ & $\begin{array}{c}\text { Glycerol } \\
1 \%\end{array}$ & $\begin{array}{c}\text { Glycerol } \\
3 \%\end{array}$ & $\begin{array}{c}\text { Glycerol } \\
5 \%\end{array}$ \\
\hline 1 & $\begin{array}{c}0.66 \pm 0.03^{\mathrm{A}} \\
(61.5 \% \pm 8.1)\end{array}$ & $\begin{array}{c}0.57 \pm 0,02^{A} \\
(54.5 \% \pm 5.5)\end{array}$ & $\begin{array}{c}0.57 \pm 0.02^{\mathrm{A}} \\
(54.0 \% \pm 6.1)\end{array}$ & $\begin{array}{c}0.60 \pm 0.02^{\mathrm{A}} \\
(57.0 \% \pm 7.1)\end{array}$ & $\begin{array}{l}0.27 \pm 0.01^{\mathrm{BC}} \\
(27.5 \% \pm 4.2)\end{array}$ & $\begin{array}{l}0.36 \pm 0.02^{\mathrm{BD}} \\
(35.5 \% \pm 6.8)\end{array}$ & $\begin{array}{c}0.380 .01^{\mathrm{BD}} \\
(55.5 \% \pm 6.4)\end{array}$ \\
\hline 2 & $\begin{array}{c}0.53 \pm 0.01^{\mathrm{A}} \\
(51.0 \% \pm 4.5)\end{array}$ & $\begin{array}{c}0.56 \pm 0.02^{A} \\
(53.0 \% \pm 6.3)\end{array}$ & $\begin{array}{c}0.52 \pm 0.02^{A} \\
(50.0 \% \pm 5.7)\end{array}$ & $\begin{array}{c}0.50 \pm 0.01^{\mathrm{A}} \\
(48.0 \% \pm 4.2)\end{array}$ & $\begin{array}{l}0.28 \pm 0.02^{\mathrm{BC}} \\
(28.0 \% \pm 6.7)\end{array}$ & $\begin{array}{l}0.36 \pm 0.01^{\mathrm{BD}} \\
(36.0 \% \pm 5.6)\end{array}$ & $\begin{array}{l}0.37 \pm 0.01^{\mathrm{BD}} \\
(36.5 \% \pm 4.1)\end{array}$ \\
\hline $\begin{array}{l}\text { Total } \\
(1+2)\end{array}$ & $\begin{array}{c}0.60 \pm 0.02^{A} \\
(56.2 \% \pm 8.4)\end{array}$ & $\begin{array}{c}0.56 \pm 0.01^{\mathrm{A}} \\
(53.7 \% \pm 5.8)\end{array}$ & $\begin{array}{c}0.54 \pm 0.01^{\mathrm{A}} \\
(52.0 \% \pm 6.1)\end{array}$ & $\begin{array}{c}0.55 \pm 0.01^{\mathrm{A}} \\
(52.5 \% \pm 7.3)\end{array}$ & $\begin{array}{l}0.28 \pm 0.01^{\mathrm{BC}} \\
(27.7 \% \pm 5.4)\end{array}$ & $\begin{array}{l}0.36 \pm 0.01^{\mathrm{BD}} \\
(35.7 \% \pm 6.1)\end{array}$ & $\begin{array}{l}0.37 \pm 0.01^{B D} \\
(36.7 \% \pm 4.9)\end{array}$ \\
\hline
\end{tabular}

Different superscript letters $(A B, C D)$ on the same line denote difference $(P<0.05)$. 
le no difference was found $(P>0.05)$ between these two higher concentrations (Table 1).

The total sperm motility did not differ among the fresh semen and those mixed with diluent after two centrifugation steps, independently of glycerol concentration. For both fresh semen and pre-freezing samples of both stallions, this motility was greater $(P<0.05)$ than those thawed samples, independently of glycerol concentration and the stallion.
Immediately after freezing, semen motility from $1 \%$ glycerol was lower $(\mathrm{P}<0.05)$ than those from 3 and $5 \%$ glycerol, while no difference $(P>0.05)$ was found between these two higher concentrations (Table 2).

The acrosome alterations evaluated only in fresh semen did not differ $(\mathrm{P}>0.05)$ between stallions and neither showed correlation $(P>0.05)$ between such alterations and acrosin activity in fresh semen $(r=0.28)$ and thawed with diluents

Table 2 Mean values $(x \pm S D)$ of data transformed by arc sen $\sqrt{ }$ and as percentages in parenthesis of sperm total motility as fresh, prefreezing, and thawed samples.

\begin{tabular}{|c|c|c|c|c|c|c|c|}
\hline \multirow[t]{3}{*}{ Animal } & \multicolumn{7}{|c|}{ Semen } \\
\hline & \multirow[b]{2}{*}{ Fresh } & \multicolumn{3}{|c|}{ Pre-Freezing } & \multicolumn{3}{|c|}{ Post-Freezing (Thawed) } \\
\hline & & $\begin{array}{c}\text { Glycerol } \\
1 \%\end{array}$ & $\begin{array}{c}\text { Glycerol } \\
3 \%\end{array}$ & $\begin{array}{c}\text { Glycerol } \\
5 \%\end{array}$ & $\begin{array}{c}\text { Glycerol } \\
1 \%\end{array}$ & $\begin{array}{c}\text { Glycerol } \\
3 \%\end{array}$ & $\begin{array}{c}\text { Glycerol } \\
5 \%\end{array}$ \\
\hline 1 & $\begin{array}{c}0.88 \pm 0.02^{A} \\
(77.0 \% \pm 4.2)\end{array}$ & $\begin{array}{c}0.82 \pm 0.02^{A} \\
(54.5 \% \pm 5.5)\end{array}$ & $\begin{array}{l}0.80^{\mathrm{A}} \pm 0.02^{\mathrm{A}} \\
(54.0 \% \pm 6.1)\end{array}$ & $\begin{array}{c}0.82 \pm 0.03^{\mathrm{A}} \\
(57.0 \% \pm 7.1)\end{array}$ & $\begin{array}{l}0.45 \pm 0.02^{\mathrm{BC}} \\
(44.0 \% \pm 6.9)\end{array}$ & $\begin{array}{l}0.55 \pm 0.02^{\mathrm{BD}} \\
(52.5 \% \pm 5.8)\end{array}$ & $\begin{array}{l}0.59 \pm 0.02^{\mathrm{BD}} \\
(55.5 \% \pm 6.4)\end{array}$ \\
\hline 2 & $\begin{array}{l}0.74 \pm 0.01^{\mathrm{A}} \\
(67.5 \% \pm 4.2)\end{array}$ & $\begin{array}{c}0.77 \pm 0.02^{A} \\
(53.0 \% \pm 6.3)\end{array}$ & $\begin{array}{l}0.754 \pm 0.02^{A} \\
(50.0 \% \pm 5.7)\end{array}$ & $\begin{array}{c}0.70 \pm 0.02^{A} \\
(48.0 \% \pm 4.2)\end{array}$ & $\begin{array}{l}0.35 \pm 0.01^{\mathrm{BC}} \\
(35.0 \% \pm 4.0)\end{array}$ & $\begin{array}{l}0.53 \pm 0.02^{\mathrm{BD}} \\
(51.0 \% \pm 5.6)\end{array}$ & $\begin{array}{l}0.54 \pm 0.02^{B D} \\
(51.5 \% \pm 6.6)\end{array}$ \\
\hline $\begin{array}{l}\text { Total } \\
(1+2)\end{array}$ & $\begin{array}{c}0.81 \pm 0.02^{A} \\
(72.2 \% \pm 6.3)\end{array}$ & $\begin{array}{c}0.80 \pm 0.01^{\mathrm{A}} \\
(71.5 \% \pm 6.0)\end{array}$ & $\begin{array}{c}0.78 \pm 0.01^{\mathrm{A}} \\
(70.2 \% \pm 5.2)\end{array}$ & $\begin{array}{l}0.76 \pm 0.02^{A} \\
(69.0 \% \pm 7.5)\end{array}$ & $\begin{array}{l}0.40 \pm 0.01^{B C} \\
(39.5 \% \pm 7.2)\end{array}$ & $\begin{array}{l}0.54 \pm 0.01^{\mathrm{D}} \\
(51.7 \% \pm 5.6)\end{array}$ & $\begin{array}{l}0.56 \pm 0.01^{\mathrm{D}} \\
(53.5 \% \pm 6.7)\end{array}$ \\
\hline
\end{tabular}

Different superscript letters $(A B, C D)$ on the same line denote difference $(P<0.05)$.

Table 3 Mean values $(x \pm S D)$ of data transformed by arc sen $\sqrt{ }$ and as percentages in parenthesis of acrosome alterations and acrosin activity as fresh, pre-freezing, and thawed samples.

\begin{tabular}{|c|c|c|c|c|c|}
\hline \multicolumn{6}{|c|}{ Acrosin } \\
\hline \multicolumn{3}{|c|}{ Acrosome } & \multicolumn{3}{|c|}{ Thawed Semen } \\
\hline Animal & $\begin{array}{l}\text { Fresh } \\
\text { semen }\end{array}$ & $\begin{array}{l}\text { Fresh } \\
\text { semen }\end{array}$ & $\begin{array}{c}\text { Glycerol } \\
1 \%\end{array}$ & $\begin{array}{c}\text { Glycerol } \\
3 \%\end{array}$ & $\begin{array}{c}\text { Glycerol } \\
5 \%\end{array}$ \\
\hline 1 & $\begin{array}{c}0.03 \pm 1.45 \\
(3.38 \% \pm 1.45)\end{array}$ & $\begin{array}{l}1.08 \pm 0.06^{A} \\
(86.7 \% \pm 9.3)\end{array}$ & $\begin{array}{c}0.75 \pm 0.06^{B} \\
(67.4 \% \pm 15.5)\end{array}$ & $\begin{array}{c}0.96 \pm 0.05^{\mathrm{AB}} \\
(80.8 \% \pm 10.4)\end{array}$ & $\begin{array}{c}0.94 \pm 0.06^{A B} \\
(79.3 \% \pm 12.6)\end{array}$ \\
\hline 2 & $\begin{array}{c}0.03 \pm 0.01 \\
(3.67 \% \pm 1.28)\end{array}$ & $\begin{array}{c}0.94 \pm 0.05^{A} \\
(79.7 \% \pm 10.5)\end{array}$ & $\begin{array}{c}0.75 \pm 0.05^{\mathrm{B}} \\
(67.8 \% \pm 13.5)\end{array}$ & $\begin{array}{c}0.84 \pm 0.04^{\mathrm{AB}} \\
(74.1 \% \pm 10.1)\end{array}$ & $\begin{array}{c}0.84 \pm 0.05^{\mathrm{AB}} \\
(74.0 \% \pm 11.4)\end{array}$ \\
\hline $\begin{array}{l}\text { Total } \\
(1+2)\end{array}$ & $\begin{array}{c}0,03 \pm 0,01 \\
(3.53 \% \pm 1.30)\end{array}$ & $\begin{array}{c}1,01 \pm 0,04^{\mathrm{A}} \\
(83.2 \% \pm 10.3)\end{array}$ & $\begin{array}{c}0,75 \pm 0,04^{\mathrm{B}} \\
(67.6 \% \pm 13.2)\end{array}$ & $\begin{array}{c}0,90 \pm 0,03^{\mathrm{AB}} \\
(77.4 \% \pm 10.5)\end{array}$ & $\begin{array}{c}0,89 \pm 0,04^{A B} \\
(76.7 \% \pm 12.0)\end{array}$ \\
\hline
\end{tabular}

Different superscript letters $(A B, C D)$ on the same line denote difference $(P<0.05)$.

Table 4 Mean values $(x \pm S D)$, of data transformed by arc sen $\sqrt{ }$ and as percentages in parenthesis of sperm motility during a thermoresistance test.

\begin{tabular}{|c|c|c|c|c|c|c|}
\hline \multirow[b]{3}{*}{ Minutes } & \multicolumn{5}{|c|}{ Semen } & \\
\hline & \multicolumn{3}{|c|}{ Animal 1} & \multicolumn{3}{|c|}{ Animal 2} \\
\hline & $\begin{array}{c}\text { Glycerol } \\
1 \%\end{array}$ & $\begin{array}{c}\text { Glycerol } \\
3 \%\end{array}$ & $\begin{array}{c}\text { Glycerol } \\
5 \%\end{array}$ & $\begin{array}{c}\text { Glycerol } \\
1 \%\end{array}$ & $\begin{array}{c}\text { Glycerol } \\
3 \%\end{array}$ & $\begin{array}{c}\text { Glycerol } \\
5 \%\end{array}$ \\
\hline 0 & $\begin{array}{l}0.45 \pm 0.02^{A} \\
(43.5 \% \pm 7.0)\end{array}$ & $\begin{array}{c}0.55 \pm 0.02^{B} \\
(52.5 \% \pm 5.8)\end{array}$ & $\begin{array}{l}0.60 \pm 0.01^{\mathrm{B}} \\
(56.5 \% \pm 4.1)\end{array}$ & $\begin{array}{c}0.35 \pm 0.01^{\mathrm{A}} \\
(35.0 \% \pm 4.0)\end{array}$ & $\begin{array}{c}0.53 \pm 0.02^{\mathrm{B}} \\
(51.0 \% \pm 5.6)\end{array}$ & $\begin{array}{c}0.54 \pm 0.02^{B} \\
(51.5 \% \pm 6.6)\end{array}$ \\
\hline 60 & $\begin{array}{c}0.20 \pm 0.02^{A} \\
(20.0 \% \pm 7.0)\end{array}$ & $\begin{array}{c}0.35 \pm 0.02^{B} \\
(34.5 \% \pm 6.8)\end{array}$ & $\begin{array}{c}0.35 \pm 0.01^{B} \\
(34.5 \% \pm 3.6)\end{array}$ & $\begin{array}{c}0.14 \pm 0.01^{\mathrm{A}} \\
(14.0 \% \pm 3.9)\end{array}$ & $\begin{array}{c}0.30 \pm 0.02^{\mathrm{B}} \\
(30.0 \% \pm 7.0)\end{array}$ & $\begin{array}{c}0.27 \pm 0.01^{\mathrm{B}} \\
(27.0 \% \pm 5.3)\end{array}$ \\
\hline 120 & $\begin{array}{l}0.07 \pm 0.01^{\mathrm{A}} \\
(7.7 \% \pm 4.5)\end{array}$ & $\begin{array}{c}0.17 \pm 0.01^{\mathrm{B}} \\
(17.0 \% \pm 5.8)\end{array}$ & $\begin{array}{c}0.15 \pm 0.01^{\mathrm{B}} \\
(15.0 \% \pm 4.7)\end{array}$ & $\begin{array}{l}0.02 \pm 0.00^{A} \\
(2.0 \% \pm 2.5)\end{array}$ & $\begin{array}{c}0.12 \pm 0.02^{B} \\
(12.5 \% \pm 7.5)\end{array}$ & $\begin{array}{l}0.09 \pm 0.01^{\mathrm{B}} \\
(9.5 \% \pm 5.5)\end{array}$ \\
\hline
\end{tabular}


containing $1 \%(r=0.41), 3 \%(r=0.49)$, and $5 \%$ glycerol $(r=0.47)$ (Table 3).

The acrosin activity in fresh semen, irrespectively of the stallion, was only greater $(\mathrm{P}<0.05)$ than those semen samples that were frozen using the diluent containing $1 \%$ glycerol (Table 3).

The total sperm motility of frozen samples with dilvent containing $1 \%$ glycerol was lower $(P<0.05)$ the $3 \%$ and $5 \%$ on the TRT, independently of the stallion. Furthermore, the semen containing concentrations of $3 \%$ and $5 \%$ of this cryoprotectant, immediately after thawing and after 60 and 120 minutes of the TRT (Table 4).

\section{Diskussion}

The initial hypothesis of this study was that sperm motility immediately after thawing, independently of glycerol concentration, should be reduced after thawing, as previously observed by several authors (Merkt and Krause 1966, Nagase et al. 1966a, Bader and Mahler 1968, Nishikawa et al. 1968, Blobel and Klug 1975, Martin et al. 1979, Ferreira-Silva et al. 2018). The acrosin activity was also described to be lower after semen thawing, as mentioned by Vieira and Klug (1982) and Ferreira-Silva et al. (2018). Such an expectation was established on the fact that cryoprotectant agents did not offer absolute protection to sperm cells during freezing and thawing steps. The results described here confirmed the hypothesis above since the motility was significantly reduced after thawing, probably due to several types of cellular injuries provoked during both freezing and thawing steps.

A similar reasoning was adopted when elaborating the project that led to this experiment. It was envisioned that the $1 \%$ glycerol concentration would allow reduced protection of sperm cells, a hypothesis that was contemplated mainly by the demonstration that this glycerol concentration does not protect sperm cells adequately. This statement is supported by sperm motility and acrosome integrity data, and low acrosin activity, that were collectively lower after thawing. Concerning sperm motility, these findings described here are not in agreement with those previously reported by Nagase et al. (1966b) and Guay et al. (1981) but agrees with more recent findings by Hoffmann et al. (2011).

A hypothesis that the $5 \%$ glycerol concentration could have been detrimental to sperm motility due to its toxicity that promotes, among other alterations, protein denaturation and modification of cytoplasmatic events of sperm cells (Hammerstedt and Graham 1992, Mclaughin et al. 1992, Curry 2000, Holt 2000). However, the data described here do not support this possibility since the motility, both progressive and total, and acrosin activity were not significantly affected. This fact was also observed by Fayer-Hosken et al. (2008) and Fayer-Hosken and Christian (2014) when using $6 \%$ and $7 \%$ glycerol, respectively. To our knowledge, these glycerol concentrations are the highest ones that can efficiently used for equine semen cryopreservation. These findings showed that the integration between diluent media formulation and cryoprotectant must have happened adequately and was crucial for not depriving sperm activity after thawing.
The initial idea that the glycerol concentration equivalent to $3 \%$ should be acceptable since it would protect sperm cells more efficiently than $1 \%$ without the possible toxicity of a $5 \%$ concentration was partially supported. It indeed confers greater protection to sperm cells than 1\%; however, it displays the same efficiency than $5 \%$, at least for the sperm parameters described above. This finding allows admitting that the concentration of $3 \%$ glycerol avoids the occurrence of important alterations in cytoplasmatic events since sperm motility and acrosin activity were unaltered after thawing. This statement is in agreement with a recent report by Ooldenhof et al. (2017), who found an optimum glycerol concentration between $2.3 \%$ and $4.6 \%$.

The ability of the stallion sperm cell after thawing to reach the ampulla of the oviduct is lower than fresh semen (Bader 1982). Due to this reason, the TRT forms an in vitro setting that reasonably allows evaluating the sperm cell potential to be transported to the site of fertilization. Therefore, it is fundamental that the semen after thawing maintains a minimum quality to be used for artificial insemination (Al). That is the a reason why it was initially established that the semen after thawing must display a minimum motility of $20 \%$ (Tischner 1979) and more recently 30\% (Loomis and Graham 2008, Hoffmann et al. 2011, Ferreira et al. 2018).

In light of these findings, it is possible to state that the semen, immediately after thawing and independently of glycerol concentration, displayed the minimum parameters required for Al. However, during the TRT, only the semen frozen with the diluent containing $3 \%$ glycerol, even after 60 minutes of the test, showed minimum motility as established by Loomis and Graham (2008), Ferreira et al. (2018) for thawed semen. Since sperm transport in the mare reproductive tract occurs rapidly and that after 60 minutes of the TRT, sperm motility of the semen with the $5 \%$ glycerol concentration still displayed almost $30 \%$ motility. Due to this fact, it is also possible to admit its usage for Al.

Other studies could be done using larger number of stallions, estimating the effect of breed or with stallions of varying semen freezing ability (Ferreira et al. 2018). These studies may provide new information about the most promising glycerol concentration for equine semen cryopreservation.

Finally, the results obtained in this study allow the conclusion, based on sperm motility and acrosin activity, that 3\% and 5\% glycerol concentrations are suitable for stallion semen cryopreservation.

\section{Acknowledgements}

Authors would like to acknowledge the Coordenação de Aperfeiçoamento de Pessoal de Nível Superior for fellowship support during the study.

\section{Animal welfare statement}

This research was performed after evaluation and approval of the Ethics Committee of the Faculdade Pio Décimo, AracajuSe, Brazil (Protocol: 01/17). 


\section{Conflict of interest statement}

None of the authors of this paper have financial or personal relationships with other people or organizations that could inappropriately influence or bias the content of the paper.

\section{References}

Amann R. P., Pickett B. W. (1987) Principles of cryopreservation and a review of cryopreservation of stallion spermatozoa. J. Equine Vet. Sci. 7, 145-173; DOI 10.1016/S0737-0806(87)80025-4

Bader $H$. (1982) An investigation of sperm migration into the oviducts of the mare. J. Reprod. Fertil. 32, 59-64

Bader V. H., Mahler R. (1968) Tiefgefrier und Besamungsversuche mit Hengstsperma unter Anwendung des Pelletverfahrenss. Zuchthygiene, 3, 6-13

Ball B. A., Vo A. (2001) Osmotic tolerance of equine spermatozoa and the effects of soluble cryoprotectants on equine sperm motility, viability, and mitochondrial membrane potential. J. Androl. 22, 1061-1069; DOI 10.1002/j.1939-4640.2001.tb03446.x

Bedford J. M. (1968) Ultrastructural changes in the sperm head during fertilization in the rabbit. Am. J. Anat., 123(2), 329-357; DOI 10.1002/aja.1001230207

Blobel K., Klug E. (1975). Tiefgefriersamen-Ubertragung beim Pferd, ein Versuch unter praktischen Gestutsbedingungen. Dtsch. Tierarztl. Wochenschr. 88, 1975

Cochran J. D., Amann R. P., Froman D. P., Pickett B. W. (1984) Effects of centrifugation, glycerol level, cooling to $5 \mathrm{C}$, freezing rate and thawing rate on the post-thaw motility of equine sperm. Theriogenology, 22, 25-38; DOI 10.1016/0093-691X(84)90470-9

Curry M. R., Kleinhans F. W., Watson P. F. (2000). Measurement of the water permeability of the membranes of boar, ram, and rabbit spermatozoa using concentration-dependent self-quenching of an entrapped fluorophore. Cryobiology 41, 167-173; DOI 10.1006 /cryo.2000.2277

Enciso M., López-Fernández C., Fernández J. L., García P., Gosálbez A., Gosálvez J. (2006) A new method to analyze boar sperm DNA fragmentation under bright-field or fluorescence microscopy. Theriogenology 65, 308-316; DOI 10.1016/i.theriogenology.2005. 05.044

Fayer-Hosken R., Abreu-Barbosa C., Heusner G. J. (2008) Cryopreservation of Stallion Spermatozoa withINRA96 and Glycerol. J. Equine Vet. Sci. 28, 672-676; DOI 10.1016/j.jevs.2008.10.006

Fayer-Hosken R.-A., Christian M. (2014) Improved techniques for freezing stallion semen as assessed by post-thaw parameters. J. Equine Vet. Sci. 34, 96-97; DOI 10.1016/i.jevs.2013.10.065

Ferreira H. N., Ferreira-Silva J. C., Rocha J. M., Fárras M. C., Calixto M., Moura M. T. Alvarenga M. A., Oliverira M. A. L. (2018) Variable inter-assay estimation of sperm DNA fragmentation in stallions classified as good and bad semen freezers. CryoLetters, Accepted

Ferreira-Silva J. C., Rocha J. M., Freitag Neto L. M., Moura M. T., Santos Filho J. P., Silva Filho M. L., Oliverira M. A. L. (2018) Freezing of stallion semen: 2 . In vitro evaluation of motility and acrosin activity in sperm cells cryopreserved using under different semen diluents. In preparation

Guay P., Rondeau M., Boucher S. (1981) Effect of glycerol on motility, viability, extracellular aspartate aminotransferase release and fertility of stallion semen before and after freezing. Equine Vet. J. 13, 177-182; DOI 10.1111/j.2042-3306.1981.tb03478.x

Hammerstedt R. H., Graham J. K. (1992) Cryopreservation of poultry sperm: the enigma of glycerol. Cryobiology 29, 26-38; DOI 10.1016/001 1-2240(92)90004-L

Hoffmann N., Oldenhof H., Morandini C., Rohn K., Sieme H. (2011) Optimal concentrations of cryoprotective agents for semen from stallions that are classified 'good' or 'poor' for freezing. Anim. Reprod. Sci. 125, 112-118; DOI 10.1016/j.anireprosci.2011. 03.001

Holt W. V. (2000) Fundamental aspects of sperm cryobiology: the importance of species and individual differences. Theriogenology 53, 47-58; DOI 10.1016/S0093-691X(99)00239-3
Loomis P. R., Graham J. K. (2008) Commercial semen freezing: individual male variation in cryosurvival and the response of stallion sperm to customized freezing protocols. Anim. Reprod. Sci. 105, 119-128; DOI 10.1016/i.anireprosci.2007.11.010

López-Fernández C., Crespo F., Arroyo F., Fernández J. L., Arana P., Johnston S. D., Gosálvez J. (2007) Dynamics of sperm DNA fragmentation in domestic animals: II. The stallion. Theriogenology 68, 1240-1250; DOI 10.1016/i.theriogenology.2007.08.029

Martin J. C., Klug E., Günzel A. R. (1979) Centrifugation of stallion semen and its storage in large volume straws. J. Reprod. Fertil. Supplement 27, 47-51

McLaughlin E. A., Ford W. C. L., Hull M. G. R. (1992) The contribution of the toxicity of a glycerol-egg yolk-citrate cryopreservative to the decline in human sperm motility during cryopreservation. J. Reprod. Fertil. 95, 749-754

Merkt H., Krause D. (1966) Experiments with deep-frozen equine semen using the so-called pellet method. Dtsch. Tierarztl. Wochenschr. 73, 267-268

Nagase H., Soejima A., Niwa T., Oshida H., Sagara Y., Ishizaki N., Hoshi S. (1966a) Studies on the freezing storage of stallion semen I. Fertility results of stallion frozen semen in concentrated pellet form. J. Anim. Reprod. 12, 48-51

Nagase H., Soejima S., Tomizuka T., Oshida H., Mikawa T., Sagara Y., Niwa T. (1966b) Studies on the freezing of stallion semen. II. Factors affecting survival rates of stallion spermatozoa after freezing and thawing and results of a fertility trial. J. Anim. Reprod. 12, 1960

Nishikawa Y., Iritani A., Shinomiya S. (1972) Studies on the protective effects of egg yolk and glycerol on the freezability of horse sperm. Int. Congr. Anim. Reprod. Artif. Insemination 2, $1545-$ 1549, [Proc]

Nishikawa Y., Waide Y., Shinomiya S. (1968) Studies on deep freezing of horse spermatozoa. Int. Congr. Anim. Reprod. Artif. Insemination, [Proc]

Oldenhof H., Bigalk J., Hettel C., de Oliverira Barros L., Sydykow B., Bajcsy A. C., Sieme H., Wolkers W. F. (2017). Stallion sperm cryopreservation using various permeating agents: interplay between concenration and cooling rate. Biopreserv Biobank. 15, 422-431; DOI 10.1089/bio.2017.0061

Pace M., Sullivan J. J. (1975) Effect of timing of insemination, numbers of spermatozoa and extender components on the pregnancy rate in mares inseminated with frozen stallion semen. J. Reprod. Fertil. Supplement 23, 115-121

Papa F. O., Felício G. B., Melo-Oña C. M., Alvarenga M. A., de Vita B., Trinque C., Dell'Aqua J. A. (201 1) Replacing egg yolk with soybean lecithin in the cryopreservation of stallion semen. Anim. Reprod. Sci. 129, 73-77; DOI 10.1016/i.anireprosci.201 1.10. 006

Penn A., Gledhill B. L., Dar Ynkiewicz Z. (1972) Modification of the gelatin substrate procedure for demonstration of acrosomal proteolytic activity. J. Histochem. Cytochem. 20, 499-506; DOI 10.1177/20.7.499

Rajamannan A. H. J. (1968) Freezing and fertility studies with stallion semen. Int. Congr. Anim. Reprod. Artif. Insemination, [Proc]

Smith A. U., Polge C. (1950) Survivalof spermatozoa at low temperatures. Nature 166, 668-669

Tischner M. (1979) Evaluation of deep-frozen semen in stallions. J. Reprod. Fertil. 27, 53-59

Vidament M., Dupere A. M., Julienne P., Evain A., Nove P., Palmer E. (1997) Equine frozen semen: freezability and fertility field results. Theriogenology 48, 907-917; DOI 10.1016/S0093-691X(97) 00319-1

Vieira R. C., Klug E. (1982) Acrosin activity as influenced by the freezing technique in equine semen. Rev. Bras. Reprod. Anim. 6, 15-20

Watson P. F. (1995) Recent developments and concepts in the cryopreservation of spermatozoa and the assessment of their post-thawing function. Reprod. Fertil. Dev. 7, 871-891; DOI 10.1071/RD 9950871

Watson P. F. (2000) The causes of reduced fertility with cryopreserved semen. Anim. Reprod. Sci. 60, 481-492; DOI 10.1016/S03784320(00)00099-3

Wendt V., Leidl W., Schill W. B. (1975) Methodische Untersuchungen zur Gelatinolyse durch Spermien. Fortschr. Fertilit. 3, 181-188 